\title{
Role of Neurogenic Inflammation in Pancreatitis and Pancreatic Pain
}

\author{
Louis Vera-Portocarrero ${ }^{a}$ Karin N. Westlund ${ }^{b}$ \\ ${ }^{a}$ Department of Pharmacology, College of Medicine, University of Arizona, Tucson, Ariz., and \\ ${ }^{b}$ Department of Neurosciences and Cell Biology, University of Texas Medical Branch, Galveston, Tex., USA
}

\section{Key Words \\ Inflammatory pain - Pancreatitis - Visceral pain}

\begin{abstract}
Pain arising from pancreatic diseases can become chronic and difficult to treat. There is a paucity of knowledge regarding the mechanisms that sensitize neural pathways that transmit noxious information from visceral organs. In this review, neurogenic inflammation is presented as a possible amplifier of the noxious signal from peripheral organs including the pancreas. The nerve pathways that transmit pancreatic pain are also reviewed as a conduit of the amplified signals. It is likely that components of these visceral pain pathways can also be sensitized after neurogenic inflammation.
\end{abstract}

Copyright $(2005$ S. Karger AG, Basel

\section{Introduction}

Pancreatitis is a clinical condition in which the main pathology is inflammation of the pancreatic tissue. The duration of the disease process serves as the main indicator for classification of this condition. Acute pancreatitis (AC) is a mild, self-limited condition, typically present with elevated serum levels of pancreatic enzymes [1]. The incidence of acute pancreatitis has been increasing over recent years [2]. Most cases are secondary to biliary disease and alcohol abuse [3]. Chronic pancreatitis (CP) of- ten represents progressive destruction of the pancreas by repeated flare-ups of silent or symptomatic acute pancreatitis [4]. During the inflammatory disease process there is a slow replacement of viable tissue by fibrotic tissue and alterations in the pancreatic nerves around the areas of inflammation [5]. The clinical incidence of chronic pancreatitis is about 4 per 100,000 inhabitants [6] but this has been rising over the last 20 years.

The symptom that most often brings the patient with pancreatitis to the clinic is abdominal pain. Pain is the only sensation that can be elicited from the pancreas [7]. Pancreatic pain is usually sensed as a severe epigastric discomfort that may radiate to the right and/or left upper quadrant and to the back [8]. Patients describe pancreatic pain as 'stabbing', 'burning', and 'boring'. There is limited functional information concerning pain in the pancreas; some inferences must be drawn from studies on the generation of pain in other viscera $[9,10]$. The etiology of pancreatic pain is a matter of controversy, ranging from neurogenic inflammation to increased pancreatic pressure. Nonetheless it is agreed that the final common pathway of any pathological process that produces pain in the pancreas is the nerve supply to this organ [4].

Neurogenic inflammation is the process by which substances released from sensory nerve terminals produce inflammation in their target tissue. This inflammation includes arteriolar vasodilation and plasma extravasation accompanied by degranulation of mast cells [11]. The principal trigger of neurogenic inflammation is the acti-

\section{KARGER}

Fax +4161306 1234 E-Mail karger@karger.ch www.karger.com
(C) 2005 S. Karger AG, Basel

$1424-862 X / 05 / 0144-0158 \$ 22.00 / 0$

Accessible online at:

www.karger.com/nsg
Prof. Karin N. Westlund High, PhD

Department of Neurosciences and Cell Biology, University of Texas Medical Branch Medical Research Bldg., Rm. 10.138D, 301 University Blvd.

Galveston, TX 77555-1043 (USA)

Tel. +1 409772 3795, Fax +1 409772 1861, E-Mail kwhigh@utmb.edu 
vation of primary afferents giving rise to dorsal root reflexes in the spinal cord [12]. The ensuing inflammation supported and perpetuated by the enhanced excitability in the spinal cord contributes to the amplification of pain signals from the periphery.

The purpose of this review is to give an overview of the currently known mechanisms of pancreatic pain transmission and evidence for the establishment of neurogenic inflammation as a possible mechanism that initiates the development of persistent transmission of pain signals from the pancreas.

\section{Pancreatic Pain}

Most of the present knowledge about pancreatic pain has come from clinical reports. Blocking or sectioning the sympathetic innervation, but not the vagus, is highly effective in managing pancreatic pain; thus visceral afferent fibers traveling with the sympathetic nerves must transmit nociceptive information from the pancreas [1318]. These sympathetic nerves pass through the celiac plexus and continue toward the central nervous system through the greater splanchnic nerves. The greater splanchnic nerves pass obliquely toward the spinal column to join the sympathetic trunk and without synapsing, the visceral afferent fibers enter the spinal cord through the spinal nerves at thoracic levels five to ten. Their cell bodies lie in the thoracic dorsal root ganglia. Signals carried by the afferent nerves serving the pancreas normally do not come to the level of consciousness. When they do, they are perceived as pain. Ascending tracts in the spinal cord carry the nerve impulses to regions of the brain, where, under the appropriate conditions, the encoded signals are perceived as pain.

It has been known for some time that limited information about visceral pain is transmitted to higher brain centers by the spinothalamic tract [19-25], the spinoreticular tract [26], the spinoparabrachial tract $[27,28]$ and pathways that project directly from the spinal cord to forebrain structures which include the amygdala and the septal nuclei [29, 30]. Recently, it has been demonstrated that a portion of the postsynaptic dorsal column pathway (PSDC), which primarily transmits discriminative tactile, vibratory and proprioceptive sensation [31-33] can transmit nociceptive signals from visceral structures, including the pancreas. Clinical evidence showed that pelvic cancer pain can be suppressed by limited neurosurgical lesions of the midline of the dorsal column pathway [34-38]. The pain was completely relieved after this sim- ple neurosurgical procedure, and large doses of morphine were no longer needed. The patients' vibratory, light touch, and proprioceptive sensation were unchanged. Cancer pain from several abdominal organs has been relieved similarly by this type of surgery [39]. Retrograde and anterograde anatomical tract tracing studies of visceral input demonstrate a neuronal pathway which arises from cell bodies situated around the central canal of the spinal cord and travels in the midline of the dorsal column to the dorsal column nuclei [40-42]. Compelling electrophysiological evidence indicates that this PSDC pathway transmits nociceptive information from the colon [43-46] and the duodenum [47]. Recently it has been demonstrated that nociceptive information from the pancreas is also transmitted by the PSDC pathway. Lesions that interrupt this pathway abolish the behavioral manifestations of visceral pain brought about by experimental pancreatic inflammation [48]. Lesions of the DC pathway also interrupt the transmission of nociceptive signals to the thalamus from the inflamed pancreas [49]. In addition to the dorsal column nuclei, the nociceptive signals from the pancreas also project to other supraspinal sensory structures such as the medial thalamus, raphe magnus, parabrachial nuclei and the periaqueductal gray [42, 50]. Thus, nociceptive transmission from the diseased pancreas reaches levels of consciousness, and is interpreted as pain, through distinct visceral pain pathways.

The origin of the pain signals from the pancreas is a matter of great discussion. Surgical drainage procedures used to treat pancreatic pain in patients with chronic pancreatitis are based on the assumption that increased pressure within the ductal system and the pancreatic parenchyma is responsible for the generation of pain. The pain relief resulted from the drainage procedure would appear to be related to a decrease in the pressure. Increased pressure causes changes in blood flow and $\mathrm{pH}$ [51] in experimental animals. Ischemia is a known stimulus of pain, and $\mathrm{H}^{+}$is also important in this regard [52].

The nerves that innervate the pancreas are mainly unmyelinated. In tissue from patients with chronic pancreatitis, foci of chronic inflammatory cells frequently are concentrated around nerves [5]. Electron-microscopic examination of pancreatic tissue from patients experiencing pain because of chronic pancreatitis shows that the chronic inflammation has damaged the nerves. The protective barrier normally provided by the perineurium is no longer intact and the nerve is edematous [5]. Inflammatory cells may invade the inner part of the nerve. Loss of the barrier makes the inner part of the nerve susceptible to factors released from the inflammatory cells (neurogenic 
inflammation, see next section) or from damaged acinar cells. These changes may initiate impulses in the affected fibers which are essential for the initiation of neurogenic inflammation.

\section{Neurogenic Inflammation}

At the turn of the 20th century, it was first demonstrated that the activation of dorsal root ganglion neurons induced vasodilation [53], suggesting that neurons not only conduct afferent information to the spinal cord, but also subserve an efferent function. The small diameter sensory neurons that are activated by capsaicin (the vanilloid found in hot peppers) are particularly important in neurogenic inflammation [54]. Intradermal injection of capsaicin rapidly produces cutaneous inflammation, which does not occur if the skin is deprived of its sensory innervation [55-57]. Thus, sensory innervation is essential for the production of neurogenic inflammation. Activation of the sensory afferents can be triggered by a variety of substances including resiniferatoxin, mustard oil, bradykinin, arachidonic acid, xylene, and acrolein, as well as by heat, ischemia, or protons [58-60]. Some of these substances are produced during a typical inflammatory response ('the inflammatory soup'), which leads to the notion that once an inflammatory response has begun, it can be perpetuated by feed forward mechanisms that results in the continual activation of the sensory primary afferent [61]. Activated primary afferents release a variety of substances in their peripheral tissue targets. Among these, the neuropeptides substance P (SP) and calcitonin gene related peptide (CGRP) have been extensively studied. Substance P released into peripheral tissues causes plasma extravasation [62-68]. This extravasation is caused by SP acting on NK-1 receptors [69]. The plasma extravasation that follows sensory stimulation is prevented by NK-1 antagonists [70-74]. The actions of SP are for the most part vasoconstrictive (endothelial cell contraction giving rise to plasma extravasation). Nonetheless there are reports that SP can act as a vasodilator in part by stimulating the release of histamine from mast cells [75-78] or by direct action that does not involve the release of histamine. Antagonists for the NK-1 receptor can also abolish the SP-produced vasodilation [79, 80]. Calcitonin gene related peptide is a potent vasodilator that in low doses causes vasodilation by direct action [81-83]. The vasodilatory action of CGRP can be attenuated by the CGRP receptor antagonist $\mathrm{CGRP}_{8-37}[84]$ which also inhibits edema formation produced by stimulation of a cutaneous nerve, suggesting that the vasodilation resulting from the release of CGRP contributes to edema formation.

The release of substances like SP and CGRP contribute to the reverberation of the inflammatory cascade in the affected tissue. Substance $P$ can act to enhance release of proinflammatory mediators into the peripheral tissue. For example SP can increase production and release of prostaglandin $\mathrm{E}_{2}$ [85], release of lysosomal enzymes [86] and release of interleukin 1 and the neutrophil chemoattractant interleukin 6 [87]. During inflammation, invading macrophages express NK-1 receptors $[88,89]$ suggesting that SP in peripheral tissues can perpetuate the inflammatory cascade. Many of these released substances can on their own sensitize neurons and enhance transmitter release, creating a reverberating circuit. For example, bradykinin can bind to the $\mathrm{B}_{2}$ receptor on sensory neurons resulting in the activation of phospholipase $\mathrm{C}$ (PLC) giving rise to the second messengers, inositol 1,4,5-trisphosphate $\left(\mathrm{IP}_{3}\right)$ and 1,2-diacylglycerol (DAG). This classical pathway increases intracellular calcium concentration and activates various isoforms of PKC [90]. Activation of PKC can potentiate neuropeptide release, as demonstrated by direct activation of the enzyme with phorbol ester on cultured neurons [91, 92]. It is possible that activation of PKC by bradykinin causes depolarization of afferent fibers. Other compounds act to sensitize sensory neurons by lowering the threshold for firing [93]. For example, the prostaglandins released into peripheral tissue and spinal cord during tissue injury and inflammation [94] lower the firing threshold of neurons [95]. Other substances that can also induce neuronal sensitization are ATP and bradykinin [96, 97]. Finally, accumulating evidence indicates that the cytokines interleukin- $1 \beta$, interleukin- 6 and tumor necrosis factor- $\alpha$ can increase the heat or capsaicin-evoked release of SP and CGRP in neuronal preparations [98, 99]. Long-term exposure to TNF- $\alpha$ also increases capsaicin currents in isolated neurons [100]. The transduction cascades that mediate cytokine sensitization actions on sensory neurons remain to be fully characterized. The actions of cytokine may be mediated in part by the release of prostaglandin, as inhibitors to COX2 can attenuate the sensitization process by cytokines [101]. The sensitizing actions of the proinflammatory prostaglandins $\mathrm{PGE}_{2}$ and $\mathrm{PGI}_{2}$ are mediated through the cAMP pathway [102]. Exposing sensory terminal endings to $\mathrm{PGE}_{2}$ or $\mathrm{PGI}_{2}$ at concentrations that can sensitize neurons will increase the production of cAMP [103, 104]. The increase in peptide release produced by prostaglandins is mimicked by forskolin, membrane-permeable 
cAMP analogs, or cholera toxin. Compounds that inhibit cAMP-dependent phosphorylation block the prostaglandin-induced sensitization [105]. Other second messenger pathways that have been implicated in the processing of neurogenic inflammation are the PKC pathway and the mitogen-activated protein (MAP) kinase pathway. The PKC pathway can be activated by ATP and bradykinin (see above), while the MAP kinase pathways can be activated by the binding of nerve growth factor (NGF) to its receptor TrkA on peptidergic sensory neuronal endings resulting in an increase in the release of neuropeptides [106].

Neurogenic inflammation has been described in numerous tissues, including the skin, joints, eye, middle ear, dura mater and in the respiratory, genitourinary, reproductive and digestive systems. One of the best-described paradigms of neurogenic inflammation is experimental inflammation of a joint. The injection of kaolin and carrageenan into the capsule of the knee joint is a very useful model of arthritis in monkeys [107]. In this model, the primary afferent fibers that supply the knee joint become much more excitable than normal. Peripheral and central changes that occur following the initiation of inflammation by injection of kaolin and carrageenan into the knee joints of rats have also been described [108]. One of the most important observations using this model is that application of either the non-NMDA receptor antagonist CNQX or the NMDA receptor antagonist AP7 by microdialysis into the dorsal horn blocked the release of excitatory amino acids brought about by inflammation of the joint. Interestingly, the swelling of the joint and the temperature rise are reduced significantly by CNQX, but not by AP7 administration [109-111]. This evidence shows how activation of spinal cord circuits can affect events in peripheral tissues. The effects observed are mediated through one of several neural pathways that connect the knee joint and the spinal cord. The involvement of the sympathetic nerves was ruled out by experiments in which surgical and chemical sympathectomy failed to reduce the amount of joint swelling [112]. The swelling also occurs when the animals are deeply anesthetized and thus have little or no muscle tone ruling out a contribution of muscle contraction. This leaves joint afferents as the most likely element involved in the central mechanism for promoting joint swelling. Experiments to validate this hypothesis recorded antidromic afferent nerve activity, referred to as dorsal root reflexes, from the medial articular nerve (MAN). The dorsal root reflexes are elicited by mechanical stimulation around the inflamed knee joint [113]. In another series of experiments recordings were

Neurogenic Inflammation in Pancreatic Pain made in rats from the MAN on the side contralateral to that of an injection of incomplete Freund's adjuvant into one knee joint [114]. Dorsal root reflexes were again observed, and local application of capsaicin to the MAN eliminated the dorsal root reflex activity. It was concluded that part of this activity is conveyed by capsaicin-sensitive articular afferents.

Antidromic stimulation of articular $\mathrm{C}$ fiber afferents has been shown to result in plasma extravasation in the knee joint [115]. Furthermore, denervation of the knee joint and administration of an SP receptor antagonist can reduce carrageenan-induced arthritis [116]. The role of CGRP in joint inflammation is not as clear as that of SP and other neurokinins, although vasodilator responses to both peptides have been shown to increase during carrageenan-induced arthritis $[112,117]$. In summary, it seems likely that dorsal root reflexes that develop in fine afferents during experimental arthritis results in the release of peptides such as SP and CGRP into the joint initiating the process of neurogenic inflammation.

\section{Neurogenic Inflammation in Pancreatitis and Its Relationship to Pain}

In visceral tissues, neurogenic inflammation may not only be a pathophysiological mechanism leading to disease, but forms part of the tissue response to injury. Neurogenic inflammation seems to be an adaptive response, promoting rapid increases in tissue substances, activating cells for local defense and enhancing fluid transport to isolate and dilute bacteria and toxins. However, this process may become maladaptive as it has been demonstrated in asthma, arthritis and migraine [118] and has been suggested also in the development of interstitial cystitis [119].

In visceral pain conditions, neurogenic inflammation seems to be a factor in the mechanism of referred pain [120]. For example, pain from myocardial infarction may sometimes induce a left seapulohumoral periarthritis, an inflammatory condition in the referred zone [121]. Evidence for neurogenic inflammation in the somatic referred zone triggered by inflammation of a viscous has been demonstrated in an animal model of uterine pain in the rat [122]. Inflammation of the uterus resulted in neurogenic plasma extravasation in the skin over the abdomen, groin, lower back and perineal areas. In the pancreas, recent investigations have implicated the involvement of neurogenic inflammation in the pathophysiology of pancreatitis. The administration of SP to mice stimu- 
lates plasma extravasation from postcapillary venules in the pancreas and this effect is blocked by antagonists to the NK-1 receptor [123]. Furthermore it has been shown that genetic deletion of the NK-1 receptor in mice reduces the severity of experimental-induced pancreatitis [124]. These findings show that SP is an important mediator of pancreatic inflammation. SP is likely to be released by nociceptive $\mathrm{c}$ fibers during pancreatitis because denervation by capsaicin reduces the severity of experimental pancreatitis [125]. The vanilloid receptor VR1 mediates SP release in the pancreas during experimental pancreatitis [126]. Receptors for SP have been found in acinar cells in the guinea pig where they act to stimulate secretion of pancreatic enzymes [127-129]. Likewise, SP can act on endothelial cell in the pancreas to produce edema [130] and can also produce its effects by activating of other inflammatory cells such as neutrophilic or mast cells $[131,132]$.

The previous evidence points to a role of SP as a proinflammatory mediator during pancreatitis, but its role as a mediator of pain and of neurogenic inflammation is still relatively unknown. The lack of a good animal model of pancreatic pain has hindered the investigation of this role. Recently, a rat model of pancreatic pain which is reliable and reproducible has been developed [133]. This model mimics the human condition by presenting signs of referred pain and responsiveness to morphine. Using this model, an antagonist to the NK-1 receptor attenuated the pain behavior seen in this model [134]. Also in this same study, NK-1 receptors were upregulated in the pancreas of animal with pancreatitis. The mechanism behind these results remains to be elucidated, but SP through the NK-1 receptors can produce plasma extravasation in the pancreas (see above) and in another model plasma extravasation has been reported [130]. In the previous section we have discussed the proinflammatory action of SP by activating proinflammatory cytokines. These cytokines can produce hyperalgesia [101] and therefore could be one of the mechanisms generating pancreatic pain. Indeed, expression of SP and IL-8 in pancreatitis are correlated [135] and the upregulation of the NK-1 receptor in the pancreas is correlated with reports of pain levels in pancreatitis [136].

\section{Concluding Remarks}

Pancreatic pain is usually very difficult to treat with conventional analgesics. It is of great importance to elucidate the mechanisms of pain during pancreatitis using appropriate models that mimic the human condition with the hope of identifying new therapeutic targets. We now know the pathways by which pancreatic pain is transmitted to higher brain centers. The possibilities of neurosurgical interventions are implicit here, but it is a proposition that likely should be reserved for cases of pancreatic cancer where the pain is intractable and/or the quality of life is very poor. Other targets have emerged as mechanisms of inflammation in the pancreas itself as an engine of reverberating activation of pancreatic nerves and subsequent neurogenic inflammation that can sensitize sensory neurons in the periphery and perpetuate a circuit that leads to persistent pain conditions.

\section{References}

1 Singer MV, Gyr K, Sarles H: Revised classification of pancreatitis: report of the Second International Symposium on the Classification of Pancreatitis in Marseille, France, March 2830, 1984. Gastroenterology 1985;89:683685.

-2 Imrie CW: Acute pancreatitis: overview. Eur J Gastroenterol Hepatol 1997;9:103-105.

3 Bhatia M, Slavin J, Cao Y, Basbaum AI, Neoptolemos JP: Preprotachykinin-A gene deletion protects mice against acute pancreatitis and associated lung injury. Am J Physiol 2003; 284:G830-G836.

4 Bockman DE, Buchler M: Pain Mechanisms; in: Beger HG, Warshaw AL, Buchler, M, CarrLocke DL, Neoptolemos JP, Russell C, Sarr MH (eds): The Pancreas. Oxford, Blackwell Science, 1998, pp 698-701.

\footnotetext{
5 Bockman DE, Buchler M, Malfertheiner P, Be- 10 Mayer EA: Clinical implications of visceral hyger HG: Analysis of nerves in chronic pancreatitis. Gastroenterology 1988;94:1459-1469.

6 Worning H: Incidence and prevalence of 11 Szolcsanyi J:Capsaicin-sensitive sensory nerve chronic pancreatitis; in Beger HG, Buchler M, Ditschuneit H, Malfertheiner P (eds): Chronic Pancreatitis. Berlin, Springer, 1990, pp 8-14.

7 Cervero F: Sensory innervation of the viscera: peripheral basis of visceral pain. Physiol Rev 1994;74:95-138.

8 Graham D, Bonica JJ: Painful diseases of the liver, biliary system and pancreas; in Loeser $\mathrm{J}$, Butler M, Chapman R, Turk D (eds): Bonica's Management of Pain. Philadelphia, Lippincott Williams \& Williams, 2001, pp 1293-1308.

-9 Mayer EA, Gebhart GF: Basic and clinical as-
} pects of visceral hyperalgesia. Gastroenterology 1994;107:271-293. 
15 Hurwitz A, Gurwittz J: Relief of pain of chronic relapsing pancreatitis by unilateral sympathectomy. Arch Surg 1950;61:372-378.

16 Rack FJ, Elkins CW: Experiences with vagotomy and sympathectomy in the treatment of chronic recurrent pancreatitis. Arch Surg 1950; 61:943.

17 Gorbitz C, Leavens ME: Alcohol block of the celiac plexus for control of upper abdominal pain caused by cancer and pancreatitis: technical note. J Neurosurg 1971;34:575-579.

- 18 Stone HH, Chauvin EJ: Pancreatic denervation for pain relief in chronic alcohol associated pancreatitis. Br J Surg 1990; 77:303-305.

19 Milne RJ, Foreman RD, Giesler GJ Jr, Willis WD: Convergence of cutaneous and pelvic visceral nociceptive inputs onto primate spinothalamic neurons. Pain 1981;11:163-183.

20 Foreman RD, Blair RW, Weber RN: Viscerosomatic convergence onto T2-T4 spinoreticular, spinoreticular-spinothalamic, and spinothalamic tract neurons in the cat. Exp Neurol 1984;85:597-619.

-21 Rucker HK, Holloway JA, Keyser GF: Response characteristics of cat spinothalamic tract neurons to splanchnic nerve stimulation. Brain Res 1984;291:383-387.

22 Ammons WS: Characteristics of spinoreticular and spinothalamic neurons with renal input. $\mathrm{J}$ Neurophysiol 1987;58:480-495.

23 Ammons WS: Primate spinothalamic cell responses to ureteral occlusion. Brain Res 1989; 496:124-130.

-24 Ammons WS: Cardiopulmonary sympathetic afferent excitation of lower thoracic spinoreticular and spinothalamic neurons. J Neurophysiol 1990;64:1907-1916.

- 25 Hobbs SF, Chandler MJ, Bolser DC, Foreman RD: Segmental organization of visceral and somatic input onto C3-T6 spinothalamic tract cells of the monkey. J Neurophysiol 1992;68: 1575-1588.

26 Lima DA: Spinomedullary projection terminating in the dorsal reticular nucleus of the rat. Neuroscience 1990;34:577-589.

-27 Cechetto DF, Standaert DG, Saper CB: Spinal and trigeminal dorsal horn projections to the parabrachial nucleus in the rat. J Comp Neurol 1985;240:153-160.

- 28 Bernard JF, Huang GF, Besson JM: The parabrachial area: electrophysiological evidence for an involvement in visceral nociceptive processes. J Neurophysiol 1994;71:1646-1660.

-29 Burstein R, Giesler GJ Jr: Retrograde labeling of neurons in spinal cord that project directly to nucleus accumbens or the septal nuclei in the rat. Brain Res 1989;497:149-154.

-30 Burstein R, Potrebic S: Retrograde labeling of neurons in the spinal cord that project directly to the amygdala or the orbital cortex in the rat. J Comp Neurol 1993;335:469-485.

- 31 Uddenberg N: Studies on modality segregation and second-order neurones in the dorsal funiculus. Experientia 1966;22:441-442.

- 32 Brown AG, Fyffe RE: Form and function of dorsal horn neurones with axons ascending the dorsal columns in cat. J Physiol 1981;321:3147.
33 Bennett GJ, Nishikawa N, Lu GW, Hoffert MJ, Dubner R: The morphology of dorsal column postsynaptic spinomedullary neurons in the cat. J Comp Neurol 1984;224:568-578.

34 Gildenberg PL, Hirshberg RM: Limited myelotomy for the treatment of intractable cancer pain. J Neurol Neurosurg Psychiatry 1984;47: 94-96.

35 Hirshberg RM, Al Chaer ED, Lawand NB, Westlund KN, Willis WD: Is there a pathway in the posterior funiculus that signals visceral pain? Pain 1996;67:291-305.

36 Nauta HJ, Hewitt E, Westlund KN, Willis WD Jr: Surgical interruption of a midline dorsal column visceral pain pathway: case report and review of the literature. J Neurosurg 1997;86: 538-542.

-37 Nauta HJ, Soukup VM, Fabian RH, Lin JT, Grady JJ, Williams CG, Campbell GA, Westlund KN, Willis WD Jr: Punctate midline myelotomy for the relief of visceral cancer pain. $\mathrm{J}$ Neurosurg 2000;92:125-130.

- 38 Becker R, Sure U, Bertalanffy H: Punctate midline myelotomy. A new approach in the management of visceral pain. Acta Neurochir (Wien) 1999;141:881-883.

-39 Kim YS, Kwon SJ: High thoracic midline dorsal column myelotomy for severe visceral pain due to advanced stomach cancer. Neurosurgery 2000;46:85-90.

40 Hirshberg RM, Al Chaer ED, Lawand NB, Westlund KN, Willis WD: Is there a pathway in the posterior funiculus that signals visceral pain? Pain 1996;67:291-305.

41 Willis WD, Al Chaer ED, Quast MJ, Westlund $\mathrm{KN}$ : A visceral pain pathway in the dorsal column of the spinal cord. Proc Natl Acad Sci USA 1999;96:7675-7679.

42 Wang CC, Willis WD, Westlund KN: Ascending projections from the area around the spinal cord central canal: a phaseolus vulgaris leucoagglutinin study in rats. J Comp Neurol 1999; 415:341-367.

43 Al Chaer ED, Lawand NB, Westlund KN, Willis WD: Pelvic visceral input into the nucleus gracilis is largely mediated by the postsynaptic dorsal column pathway. J Neurophysiol 1996; 76:2675-2690.

44 Al Chaer ED, Lawand NB, Westlund KN, Willis WD: Visceral nociceptive input into the ventral posterolateral nucleus of the thalamus: a new function for the dorsal column pathway. J Neurophysiol 1996;76:2661-2674.

-45 Al Chaer ED, Westlund KN, Willis WD: Potentiation of thalamic responses to colorectal distension by visceral inflammation. Neuroreport 1996; 7:1635-1639.

46 Al Chaer ED, Feng Y, Willis WD: A role for the dorsal column in nociceptive visceral input into the thalamus of primates. J Neurophysiol 1998;79:3143-3150.

47 Feng Y, Cui M, Al Chaer ED, Willis WD: Epigastric antinociception by cervical dorsal column lesions in rats. Anesthesiology 1998;89: 411-420.
48 Houghton AK, Hewitt E, Westlund KN: Enhanced withdrawal responses to mechanical and thermal stimuli after bone injury. Pain 1997; 73:325-337.

49 Houghton AK, Wang CC, Westlund KN: Do nociceptive signals from the pancreas travel in the dorsal column? Pain 2001;89:207-220.

- 50 Wang CC, Westlund KN: Responses of rat dorsal column neurons to pancreatic nociceptive stimulation. Neuroreport 2001;12:25272530.

-51 Patel AG, Toyama MT, Ashley SW, Benjamin IS, Reber HA: Duct decompression in chronic pancreatitis: effects on blood flow and interstitial pH. Br J Surg 1994;81:1816.

52 Stahl GL, Longhurst JC: Ischemically sensitive visceral afferents: importance of $\mathrm{H}+$ derived from lactic acid and hypercapnia. Am J Physiol 1992;262:H748-H753.

53 Bayliss WM: On the origin from the spinal cord of the vaso-dilator fibres of the hind-limb and on the nature of these fibers. J Physiol 1901;26: 173-209.

54 Holzer P: Local effector functions of capsaicinsensitive sensory nerve endings: involvement of tachykinins, calcitonin gene-related peptide and other neuropeptides. Neuroscience 1988; 24:739-768.

55 Jancso N, Jancso-Gabor A, Szolcsanyi J: The role of sensory nerve endings in neurogenic inflammation induced in human skin and in the eye and paw of the rat. Br J Pharmacol 1968; 33:32-41.

-56 Lundblad L, Lundberg JM, Anggard A, Zetterstrom O: Capsaicin-sensitive nerves and the cutaneous allergy reaction in man. Possible involvement of sensory neuropeptides in the flare reaction. Allergy 1987;42:20-25.

57 Buck SH, Burks TF: The neuropharmacology of capsaicin: review of some recent observations. Pharmacol Rev 1986;38:179-226.

58 Dray A: Afferent responses of sensory neurons; in Geppetti P, Holzer P (eds): Neurogenic Inflammation. Boca Raton, CRC Press, 1996, pp 69-79.

59 Maggi CA: The pharmacological modulation of neurotransmitter release; in Wood JN (ed): Capsaicin in the Study of Pain. London, Academic Press, 1993, pp 161-189.

60 Maggi CA: Pharmacology of the efferent function of primary sensory neurons; in Geppetti P, Holzer P (eds): Neurogenic Inflammation. Boca Raton, CRC Press, 1996, pp 81-90.

-61 Sluka KA, Rees H, Westlund KN, Willis WD: Fiber types contributing to dorsal root reflexes induced by joint inflammation in cats and monkeys. J Neurophysiol 1995;74:981-989.

62 Chahl LA: The effect of putative peptide neurotransmitters on cutaneous vascular permeability in the rat. Naunyn Schmiedebergs Arch Pharmacol 1979;309:159-163.

63 Lembeck F, Holzer P: Substance P as neurogenic mediator of antidromic vasodilation and neurogenic plasma extravasation. Naunyn Schmiedebergs Arch Pharmacol 1979;310: 175-183. 
-64 Foreman JC, Jordan CC, Oehme P, Renner H: Structure-activity relationships for some substance P-related peptides that cause wheal and flare reactions in human skin. J Physiol 1983; 335:449-465.

- 65 Saria A, Lundberg JM, Skofitsch G, Lembeck $\mathrm{F}$ : Vascular protein linkage in various tissue induced by substance $\mathrm{P}$, capsaicin, bradykinin, serotonin, histamine and by antigen challenge. Naunyn Schmiedebergs Arch Pharmacol 1983; 324:212-218.

-66 Fuller RW, Conradson TB, Dixon CM, Crossman DC, Barnes PJ: Sensory neuropeptide effects in human skin. Br J Pharmacol 1987;92: 781-788.

67 Wallengren J, Hakanson R: Effects of substance $\mathrm{P}$, neurokinin A and calcitonin gene-related peptide in human skin and their involvement in sensory nerve-mediated responses. Eur J Pharmacol 1987;143:267-273.

-68 Jacques L, Couture R, Drapeau G, Regoli D: Capillary permeability induced by intravenous neurokinins: receptor characterization and mechanism of action. Naunyn Schmiedebergs Arch Pharmacol 1989;340:170-179.

69 Iwamoto I, Nadel JA: Tachykinin receptor subtype that mediates the increase in vascular permeability in guinea pig skin. Life Sci 1989;44: 1089-1095.

-70 Lembeck F, Donnerer J, Bartho L: Inhibition of neurogenic vasodilation and plasma extravasation by substance $P$ antagonists, somatostatin and [D-Met2, Pro5] enkephalinamide. Eur J Pharmacol 1982;85:171-176.

71 Lundberg JM, Saria A, Rosell S, Folkers K: A substance $\mathrm{P}$ antagonist inhibits heat-induced oedema in the rat skin. Acta Physiol Scand 1984;120:145-146.

-72 Saria A, Hua X, Skofitsch G, Lundberg JM: Inhibition of compound 48/80-induced vascular protein leakage by pretreatment with capsaicin and a substance $\mathrm{P}$ antagonist. Naunyn Schmiedebergs Arch Pharmacol 1984;328:9_ 15.

73 Khalil Z, Helme RD: Sequence of events in substance P-mediated plasma extravasation in rat skin. Brain Res 1989;500:256-262.

74 Lembeck F, Donnerer J, Tsuchiya M, Nagahisa A: The non-peptide tachykinin antagonist, CP-96,345, is a potent inhibitor of neurogenic inflammation. Br J Pharmacol 1992;105:527530.

75 Lembeck F, Holzer P: Substance P as neurogenic mediator of antidromic vasodilation and neurogenic plasma extravasation. Naunyn Schmiedebergs Arch Pharmacol 1979;310: 175-183.

76 Carpenter SE, Lynn B: Vascular and sensory responses of human skin to mild injury after topical treatment with capsaicin. Br J Pharmacol 1981;73:755-758.

77 Woodward DF, Owen DA, Pipkin MA, Ledgard SE: Histamine involvement in the local and systemic microvascular effects produced by intradermal substance P. Agents Actions 1985;17:126-130.
Andrews PV, Helme RD: Tachykinin-induced vasodilatation in rat skin measured with a laser-Doppler flowmeter: evidence for receptormediated effects. Regul Pept 1989;25:267275 .

79 Couture R, Cuello AC: Studies on the trigeminal antidromic vasodilatation and plasma extravasation in the rat. J Physiol 1984;346:273285

$80 \mathrm{Xu}$ XJ, Hao JX, Wiesenfeld-Hallin Z, Hakanson R, Folkers K, Hokfelt T: Spantide II, a novel tachykinin antagonist, and galanin inhibit plasma extravasation induced by antidromic C-fiber stimulation in rat hindpaw. Neuroscience 1991;42:731-737.

81 Brain SD, Williams TJ, Tippins JR, Morris HR, MacIntyre I: Calcitonin gene-related peptide is a potent vasodilator. Nature $1985 ; 313$ : 54-56.

82 Pedersen-Bjergaard U, Nielsen LB, Jensen K, Edvinsson L, Jansen I, Olesen J: Calcitonin gene-related peptide, neurokinin A and substance P: effects on nociception and neurogenic inflammation in human skin and temporal muscle. Peptides 1991;12:333-337.

83 Escott KJ, Brain SD: Effect of a calcitonin gene-related peptide antagonist (CGRP8-37) on skin vasodilatation and oedema induced by stimulation of the rat saphenous nerve. Br J Pharmacol 1993;110:772-776.

84 Hughes SR, Brain SD: A calcitonin gene-related peptide (CGRP) antagonist (CGRP8-37) inhibits microvascular responses induced by CGRP and capsaicin in skin. Br J Pharmacol 1991;104:738-742.

85 Lotz M, Carson DA, Vaughan JH: Substance $P$ activation of rheumatoid synoviocytes: neural pathway in pathogenesis of arthritis. Science 1987;235:893-895.

86 Johnson AR, Erdos EG: Release of histamine from mast cells by vasoactive peptides. Proc Soc Exp Biol Med 1973;142:1252-1256.

87 Lotz M, Vaughan JH, Carson DA: Effect of neuropeptides on production of inflammatory cytokines by human monocytes. Science 1988 ; 241:1218-1221.

88 Ho WZ, Lai JP, Zhu XH, Uvaydova M, Douglas SD: Human monocytes and macrophages express substance $\mathrm{P}$ and neurokinin-1 receptor. J Immunol 1997;159:5654-5660.

89 Lai L, Alaverdi N, Maltais L, Morse HC: III Mouse cell surface antigens: nomenclature and immunophenotyping. J Immunol 1998;160 3861-3868.

90 Burgess GM, Mullaney I, McNeill M, Dunn PM, Rang, HP: Second messengers involved in the mechanism of action of bradykinin in sensory neurons in cultureJ Neurosci 1989;9: 3314-3325.

91 Barber LA, Vasko MR: Activation of protein kinase $\mathrm{C}$ augments peptide release from rat sensory neurons. J Neurochem 1996;67:7280.

92 Vellani V, Mapplebeck S, Moriondo A, Davis $\mathrm{JB}, \mathrm{McNaughton}$ PA: Protein kinase $\mathrm{C}$ activation potentiates gating of the vanilloid receptor VR1 by capsaicin, protons, heat and anandamide. J Physiol 2001;534:813-825.
-93 Richardson JD, Vasko MR: Cellular mechanisms of neurogenic inflammation. J Pharmacol Exp Ther 2002;302:839-845.

94 Dirig DM, Yaksh TL: Spinal synthesis and release of prostanoids after peripheral injury and inflammation. Adv Exp Med Biol 1999; 469:401-408

95 Schaible HG, Schmidt RF: Excitation and sensitization of fine articular afferents from cat's knee joint by prostaglandin $E_{2}$. J Physiol 1988;403:91-104

-96 Beck PW, Handwerker HO: Bradykinin and serotonin effects on various types of cutaneous nerve fibers. Pfluegers Arch 1974;347: 209-222.

97 Tominaga M, Wada M, Masu M: Potentiation of capsaicin receptor activity by metabotropic ATP receptors as a possible mechanism for ATP-evoked pain and hyperalgesia. Proc Natl Acad Sci USA 2001;98:69516956.

98 Inoue A, Ikoma K, Morioka N, Kumagai K, Hashimoto T, Hide I, Nakata Y: Interleukinlbeta induces substance $\mathrm{P}$ release from primary afferent neurons through the cyclooxygenase-2 system. J Neurochem 1999;73: 2206-2213.

99 Opree A, Kress M: Involvement of the proinflammatory cytokines tumor necrosis factoralpha, IL- 1 beta, and IL- 6 but not IL-8 in the development of heat hyperalgesia: effects on heat-evoked calcitonin gene-related peptide release from rat skin. J Neurosci 2000;20: 6289-6293.

100 Nicol GD, Lopshire JC, Pafford CM: Tumor necrosis factor enhances the capsaicin sensitivity of rat sensory neurons. J Neurosci 1997; 17:975-982.

101 Watkins LR, Maier SF: The pain of being sick: implications of immune-to-brain communication for understanding pain. Annu Rev Psychol 2000;51:29-57.

102 Southall MD, Vasko MR: Prostaglandin receptor subtypes, EP3C and EP4, mediate the prostaglandin $\mathrm{E}_{2}$-induced cAMP production and sensitization of sensory neurons. J Biol Chem 2001;276:16083-16091

103 Hingtgen CM, Waite KJ, Vasko MR: Prostaglandins facilitate peptide release from rat sensory neurons by activating the adenosine $3^{\prime}, 5^{\prime}$-cyclic monophosphate transduction cascade. J Neurosci 1995; 15:5411-5419.

104 Smith JA, Amagasu SM, Eglen RM, Hunter JC, Bley KR: Characterization of prostanoid receptor-evoked responses in rat sensory neurones. Br J Pharmacol 1998;124:513-523.

105 Cui M, Nicol GD: Cyclic AMP mediates the prostaglandin E2-induced potentiation of bradykinin excitation in rat sensory neurons. Neuroscience 1995;66:459-466.

106 Ganju P, O’Bryan JP, Der C, Winter J, James IF: Differential regulation of SHC proteins by nerve growth factor in sensory neurons and PC12 cells. Eur J Neurosci 1998;10:19952008.

Vera-Portocarrero/Westlund 
107 Schaible HG, Grubb BD: Afferent and spinal mechanisms of joint pain. Pain 1993;55: 5-54.

108 Sluka KA, Westlund KN: An experimental arthritis in rats: dorsal horn aspartate and glutamate increases. Neurosci Lett 1992;145: 141-144.

109 Sluka KA, Westlund KN: Spinal cord amino acid release and content in an arthritis model: the effects of pretreatment with non-NMDA, NMDA, and NK1 receptor antagonists. Brain Res 1993;627:89-103.

-110 Sluka KA, Westlund KN: Centrally administered non-NMDA but not NMDA receptor antagonists block peripheral knee joint inflammation. Pain 1993;55:217-225.

111 Sluka KA, Jordan HH, Westlund KN: Reduction in joint swelling and hyperalgesia following post-treatment with a non-NMDA glutamate receptor antagonist. Pain 1994;59: 95-100.

112 Sluka KA, Lawand NB, Westlund KN: Joint inflammation is reduced by dorsal rhizotomy and not by sympathectomy or spinal cord transection. Ann Rheum Dis 1994;53:309314.

-113 Sluka KA, Rees H, Westlund KN, Willis WD: Fiber types contributing to dorsal root reflexes induced by joint inflammation in cats and monkeys. J Neurophysiol 1995;74:981-989.

114 Rees H, Sluka KA, Lu Y, Westlund KN, Willis WD: Dorsal root reflexes in articular afferents occur bilaterally in a chronic model of arthritis in rats. J Neurophysiol 1996;76: 4190-4193.

115 Ferrell WR, Russell NJ: Extravasation in the knee induced by antidromic stimulation of articular C fibre afferents of the anaesthetized cat. J Physiol 1986;379:407-416.

116 Lam FY, Ferrell WR: Inhibition of carrageenan induced inflammation in the rat knee joint by substance $\mathrm{P}$ antagonist. Ann Rheum Dis 1989;48:928-932.

117 Lam FY, Ferrell WR: Acute inflammation in the rat knee joint attenuates sympathetic vasoconstriction but enhances neuropeptidemediated vasodilatation assessed by laser Doppler perfusion imaging. Neuroscience 1993;52:443-449.
118 Geppetti P, Holzer P: Neurogenic inflammation. Boca Raton, CRC Press, 1996.

119 Elbadawi A: Interstitial cystitis: a critique of current concepts with a new proposal for pathologic diagnosis and pathogenesis. Urology 1997;49:14-40.

120 Procacci P, Marcesca M: Referred pain from somatic and visceral strutures. Curr Rev Pain 1999;3:96-99.

121 Procacci P, Zoppi M, Marcesca M: Heart, vascular and haemopathic pain; in Wall PD, Melzack R (eds): Textbook of Pain. New York, Churchill-Livingstone, 1999, pp 621639.

122 Wesselmann U, Lai J: Mechanisms of referred visceral pain: uterine inflammation in the adult virgin rat results in neurogenic plasma extravasation in the skin. Pain 1997;73: 309-317.

123 Figini M, Emanueli C, Grady EF, Kirkwood K, Payan DG, Ansel J, Gerard C, Geppetti P, Bunnett N: Substance $P$ and bradykinin stimulate plasma extravasation in the mouse gastrointestinal tract and pancreas. Am J Physiol 1997;272:G785-G793.

124 Bhatia M, Saluja AK, Hofbauer B, Frossard JL, Lee HS, Castagliuolo I, Wang CC, Gerard N, Pothoulakis C, Steer ML: Role of substance $\mathrm{P}$ and the neurokinin 1 receptor in acute pancreatitis and pancreatitis-associated lung injury. Proc Natl Acad Sci USA 1998;95: 4760-4765.

125 Nathan JD, Peng RY, Wang Y, McVey DC, Vigna SR, Liddle RA: Primary sensory neurons: a common final pathway for inflammation in experimental pancreatitis in rats. Am J Physiol 2002;283:G938-G946.

126 Nathan JD, Patel AA, McVey DC, Thomas JE, Prpic V, Vigna SR, Liddle RA: Capsaicin vanilloid receptor-1 mediates substance $\mathrm{P}$ release in experimental pancreatitis. Am J Physiol 2001;281:G1322-G1328.
127 Sjodin L, Dahlen HG, Gylfe E: Calcium oscillations in guinea-pig pancreatic acinar cells exposed to carbachol, cholecystokinin and substance P. J Physiol 1991;444:763-776.

128 Sjodin L, Viitanen E, Gylfe E: Rapid downregulation of substance $\mathrm{P}$ binding to guineapig pancreatic acinar cells during homologous desensitization. J Physiol 1994;476:69-77.

129 Song SY, Iwashita S, Noguchi K, Konishi S: Inositol trisphosphate-linked calcium mobilization couples substance $P$ receptors to conductance increase in a rat pancreatic acinar cell line. Neurosci Lett 1988;95:143-148.

130 Grady EF, Yoshimi SK, Maa J, Valeroso D, Vartanian RK, Rahim S, Kim EH, Gerard C, Gerard N, Bunnett NW, Kirkwood KS: Substance $\mathrm{P}$ mediates inflammatory oedema in acute pancreatitis via activation of the neurokinin-1 receptor in rats and mice. Br J Pharmacol 2000;130:505-512.

131 Carolan EJ, Casale TB: Effects of neuropeptides on neutroph il migration through noncellular and endothelial barriers. J Allergy Clin Immunol 1993;92:589-598.

132 Roch-Arveiller M, Regoli D, Chanaud B, Lenoir M, Muntaner O, Stralzko S, Giroud JP: Tachykinins: effects on motility and metabolism of rat polymorphonuclear leucocytes. Pharmacology 1986;33:266-273.

133 Vera-Portocarrero LP, Lu Y, Westlund KN: Nociception in persistent pancreatitis in rats: effects of morphine and neuropeptide alterations. Anesthesiology 2003;98:474-484.

134 Vera-Portocarrero LP, Westlund KN: Attenuation of nociception in a model of acute pancreatitis by an NK-1 antagonist. Pharmacol Biochem Behav 2004;77:631-640.

135 Di Sebastiano P, di Mola FF, Di Febbo C, Baccante G, Porreca E, Innocenti P, Friess H, Buchler MW: Expression of interleukin 8 (IL8 ) and substance $P$ in human chronic pancreatitis. Gut 2000;47:423-428.

-136 Shrikhande SV, Friess H, di Mola FF, Tempia-Caliera A, Conejo G. Jr, Zhu Z, Zimmermann A, Buchler MW: NK-1 receptor gene expression is related to pain in chronic pancreatitis. Pain 2001;91:209-217. 